\title{
Synthesis of magnetic recoverable electron-rich TCTA@PVP based conjugated polymer for photocatalytic water remediation and disinfection
}

\author{
Ridha Djellabi ${ }^{\mathrm{a}, \mathrm{b}}$, Jafar Ali ${ }^{\mathrm{c}}$, Bo Yang ${ }^{\mathrm{b}}$, Muhammad Rizwan Haider ${ }^{\mathrm{d}}$, Peidong Su ${ }^{\mathrm{a}, \mathrm{b}}$, \\ Claudia L. Bianchi ${ }^{\mathrm{e}}$, Xu Zhao ${ }^{\mathrm{a}, *}$ \\ ${ }^{a}$ Key Laboratory of Drinking Water Science and Technology, Research Center for Eco-Environmental Sciences, Chinese Academy of Sciences, Beijing, PR China \\ ${ }^{\mathrm{b}}$ Department of Environmental Engineering, College of Chemistry and Environmental Engineering, Shenzhen University, Shenzhen, PR China \\ ${ }^{\mathrm{c}}$ Key Laboratory of Environmental Nanotechnology and Health Effects, Research Center for Eco-environmental Sciences, Chinese Academy of Sciences, Beijing, PR China \\ ${ }^{\mathrm{d}}$ Key Laboratory of Environmental Biotechnology, Research Center for Eco-Environmental Sciences, Chinese Academy of Sciences, Beijing, PR China \\ ${ }^{\mathrm{e}}$ Department of Chemistry, Università degli Studi di Milano, Via Golgi 19, Milano, Italy
}

A R T I C L E I N F O

\section{Keywords:}

Conjugated polymer

Magnetic recovery

Water remediation \& disinfection

Photocatalysis

\begin{abstract}
A B S T R A C T
In this study, we report the synthesis of magnetic electron-rich $\mathrm{CP} @ \mathrm{Fe}_{3} \mathrm{O}_{4}$ (Conjugated Polymer (CP) = TCTAPVP-bipyridine) by hydrothermal method. For this aim, the $\mathrm{Fe}_{3} \mathrm{O}_{4}$ nanoparticles were incorporated into photoactive TCTA-PVP-bipyridine based Conjugated Polymer. The photo-redox abilities of $\mathrm{CP} @ \mathrm{Fe}_{3} \mathrm{O}_{4}$ and bare $\mathrm{CP}$ were tested for oxidation of methylene blue and reduction of $\mathrm{Cr}(\mathrm{VI})$ under UV-visible light and visible light $(\lambda>420 \mathrm{~nm})$. The $\mathrm{CP} @ \mathrm{Fe}_{3} \mathrm{O}_{4}$ showed a good ability for performing the Fenton-like reaction by adding $\mathrm{H}_{2} \mathrm{O}_{2}$ as oxidizing agent. Additionally, reveals high photocatalytic reduction ability of $\mathrm{Cr}(\mathrm{VI})$ for $\mathrm{CP} @ \mathrm{Fe}_{3} \mathrm{O}_{4}$ in compare with bare CP. Furthermore the photocatalytic antibacterial ability of $\mathrm{CP} @ \mathrm{Fe}_{3} \mathrm{O}_{4}$ towards E. coli and Pseudomonas Aerogenosa in water was studied. The obtained CFU reduction efficiencies were found about $85 \%$ and $90 \%$ for $E$. coli and P. Aeruginosa, respectively. Interestingly the collecting and recyclability of $\mathrm{CP} @ \mathrm{Fe}_{3} \mathrm{O}_{4}$ after photocatalytic reactions were done easily due to its magnetic property.
\end{abstract}

\section{Introduction}

The quality of surface and groundwaters influences directly all aspects of humankind.

Industries are most likely the main source of discharged contaminated wastewaters with varying types of toxic compounds including organics, heavy metals and microorganisms. Therefore, water pollution and its treatment has become the most serious concern and a challenging task for the public authorities and industrial world [1]. Due to the huge urbanization and industrialization growth, which is associated with large wastewaters discharged into the environment that overloading the ecosystem, the European Water Framework Directive (WFD) has classified chemical substances into two main categories, namely 'Black List' that includes all highly toxic and non-biodegradable chemicals; and 'Grey List' which involves chemicals that can cause a serious risk to the ecosystem. For clean environment, contaminated industrial wastewaters must be properly treated at the source before discharging them into the environment. The adequate treatment of industrial wastewaters requires usually the combination of different processes because of the complicated nature of such contaminated waters. The choice of the specific treatment processes mainly depends on several parameters such as the nature and concentration of pollutants in wastewaters, less secondary-waste formation, the simplicity of set-up and cost, the treatment efficiency and so on.

Over more than three decades, heterogeneous photocatalysis for water remediation has traveled an extended path of technological development $[2,3]$. Photocatalysis system has the competence of continuous oxidizing or reducing a wide range of pollutants in water without producing any toxic secondary waste. Since the efficiency of a photocatalytic treatment system for a targeted contaminated water is directly related to the characteristics of the used photocatalyst, many efforts have been made at a blistering rate aiming to develop novel photoactive materials with better physical and optical characteristics for real-world applications [4,5].

For the sake of enhancing the visible light response (VLR) of photocatalytic materials (i.e., $\mathrm{TiO}_{2}$ ), band gap engineering was the cornerstone of photocatalytic materials science, therefore, an extensive research has been reported regarding the synthesis of VLR materials through many approaches such as metal and non-metal doping [6-8], dye sensitizing $[9,10]$, semiconductor heterojunction photocatalysts

\footnotetext{
* Corresponding author.

E-mail address: zhaoxu@rcees.ac.cn (X. Zhao).
} 
$[11,12]$ and combination of photocatalysts with carbonaceous materials $[13,14]$. Apart from that, the appropriate use of photocatalyst (supported or suspended in water) for real wastewater treatment has been widely discussed in the literature [15]. Briefly, it was deduced that the dispersed photocatalysts exhibit higher photocatalytic efficiency compared to supported photocatalysts because the immobilized photocatalyst suffers from the low surface area, low irradiated surface and less mass transfer. On contrast, the need of costly post recovery of suspended photocatalyst from water after the treatment is the main issue due to the small sized particles. Therefore, such a trade-off between the high efficiency and the hard recovery of suspended particles must be investigated. For better controllability and easy recovery of the photocatalyst suspension, many studies have been reported on the exploitation of magnetic materials in water remediation [16-19]. Suspended powder-like magnetic photocatalysts can be easily gathered after the treatment via the use of external magnetic field, which indeed facilities the regeneration of the photocatalyst and its reuse. Besides, on top of the magnetic propriety and high stability of $\mathrm{Fe}_{3} \mathrm{O}_{4}$, it can be also itself photocatalyst to produce reactive oxygen species (ROSs) or electrons under light, or it can catalyze some reactions (i.e., Fenton reaction, Electro-Fenton) [20-23]. On the other hand, some reports mentioned that the introduction of $\mathrm{Fe}_{3} \mathrm{O}_{4}$ to some semiconductors (i.e., $\mathrm{TiO}_{2}$ ) can result in better $\mathrm{e}^{-} / \mathrm{h}^{+}$charges separation and VLR [24]. In this study, magnetic $\mathrm{Fe}_{3} \mathrm{O}_{4}$ was introduced into the electron-rich photoactive TCTA-PVP based conjugated polymer (CP) for better recovery and synergistic photocatalytic effect. The photocatalytic ability of magnetic $\mathrm{CP} @ \mathrm{Fe}_{3} \mathrm{O}_{4}$ was tested for different types of pollutant that usually exist in wastewaters such as $\mathrm{Cr}(\mathrm{VI})$ reduction, methylene blue degradation and for the inactivation of two types of common bacteria in wastewaters (E. coli and Pseudomonas Aeruginosa (PA)) that are known as major faecal contaminant in water purification systems as well $[25,26]$.

\section{Experimental section}

\subsection{Synthesis and characterization of materials}

TCTA@PVP based conducting polymer (CP) was synthesized by heat polymerization of Tris(4-carbazoyl-9-ylphenyl)amine (TCTA), PVP and $4,4^{\prime}$-bipyridine at $70{ }^{\circ} \mathrm{C}$ until the color of the mixture changed to orange. The obtained mixture was dried at $90{ }^{\circ} \mathrm{C}$ for $48 \mathrm{~h}$ and was calcined at $250{ }^{\circ} \mathrm{C}$ for $1 \mathrm{~h}$ for transformation of the prepared gel to solid blocks.

$\mathrm{Fe}_{3} \mathrm{O}_{4}$ nanoparticles were synthesized by hydrothermal method [17]. A desired amount of $\mathrm{Fe}_{3} \mathrm{Cl} \cdot 6 \mathrm{H}_{2} \mathrm{O}$ was dissolved in $50 \mathrm{~mL}$ of deionizd water, and sonicated for $30 \mathrm{~min}$ at room temperature. The mixture was transferred into a sealed, Teflon-lined autoclave and was heated at $180{ }^{\circ} \mathrm{C}$ for $6 \mathrm{~h}$. After cooling the mixture to room temperature, the powder was washed several times with distilled water and dried at $60{ }^{\circ} \mathrm{C}$ for $12 \mathrm{~h}$.

$\mathrm{CP} @ \mathrm{Fe}_{3} \mathrm{O}_{4}$ was synthesized via the introduction of $\mathrm{Fe}_{3} \mathrm{O}_{4}$ particles into the $\mathrm{CP}$ orange mixture, and the drying and calcination procedures were continuous. The ratio of $\mathrm{CP}: \mathrm{Fe}_{3} \mathrm{O}_{4}(\mathrm{~g} / \mathrm{g})$ was $8: 2$.

Materials were characterized by UV-vis Diffuse Reflectance Spectroscopy (UV-DRS), Scanning Electron Microscopy combined with Energy Dispersive Analysis of X-rays (SEM-EDAX), X-ray diffraction (XRD), X-ray Photoelectron Spectroscopy (XPS), Thermogravimetry Differential Scanning Calorimetry (TG-DSC). Cyclic Voltammetry (CV) and Linear Sweep Voltammetry (LSV). TG-DSC was performed on noncalcined photocatalyst samples (the samples after the polymerization were dried at $90^{\circ} \mathrm{C}$ for $48 \mathrm{~h}$ and then the powder was directly subjected to TG/DSC analysis) using TG/DSC Mettler Toledo from room temperature to $600{ }^{\circ} \mathrm{C}$ with a heating rate of $10{ }^{\circ} \mathrm{C} / \mathrm{min}$ under $\mathrm{N}_{2}$ atmosphere.

\subsection{Photocatalytic experiments}

The photocatalytic activities of synthesized materials for degradation of methylene blue dye solution, reduction of hexavalent chromium and inactivation of Escherichia coli (E. coli) and Pseudomonas Aeruginosa $(P A)$ in water were studied. PLS-SXE300 Xenon lamp light (PerfectLight) equipped with a quartz UV cut-off filter $(\lambda>420 \mathrm{~nm})$ was used for the irradiation. The photocatalytic experiments for MB or $\mathrm{Cr}(\mathrm{VI})$ removal were carried by mixing $0.25 \mathrm{~g} / \mathrm{L}$ of the photocatalyst with $\mathrm{MB}$ or $\mathrm{Cr}(\mathrm{VI})$ solutions under visible light. Aliquots of solution at certain time interval were taken and filtered, and the analysis of $\mathrm{Cr}(\mathrm{VI})$ and $\mathrm{MB}$ concentrations determined by UV/Vis spectrophotometry at 540 and 662 , respectively.

The photocatalytic antibacterial activity of $\mathrm{CP} @ \mathrm{Fe}_{3} \mathrm{O}_{4}$ composite was evaluated against the Escherichia coli and Pseudomonas aeruginosa. Purified gram-negative bacterial strains were obtained from the Key Laboratory of Environmental Nanotechnology and Health Effects, CAS, Beijing. The LB broth was used to refresh the culture for further applications in antibacterial tests. The photocatalytic antibacterial activity of $\mathrm{Fe}_{3} \mathrm{O}_{4} @ \mathrm{CP}$ against both gram negative bacteria was validated through viability of bacterial cells by spread plate method. The spread plate method shows the number of colony forming units (CFU) on plate counter agar. The photocatalytic inactivation of bacteria was evaluated by mixing, in $20 \mathrm{~mL}$ test tubes, $20 \mathrm{mg}$ of $\mathrm{CP} @ \mathrm{Fe}_{3} \mathrm{O}_{4}$ with $15 \mathrm{~mL}$ of LB broth and $1 \mathrm{~mL}$ of each type of bacteria having $1 \times 10^{7} \mathrm{CFU} \mathrm{mL}^{-1}$. LB broth contains $10 \mathrm{gL}^{-1}$ of peptone, $5 \mathrm{gL}^{-1}$ of yeast extract and $10 \mathrm{~g} / \mathrm{L}$ $\mathrm{gL}^{-1}$ of $\mathrm{NaCl}$. Then, test tubes were shacked using Tube Swing Rotary Shaker under PLS-SXE300 Xenon lamp light irradiation (300-1100 nm) at room temperature. Similar test tubes under light without photocatalyst were used as controls. After 2 and 4 h, $200 \mu \mathrm{L}$ aliquots were aseptically taken out to spread on agar plates. Finally, all the spread agar plates were incubated at $37{ }^{\circ} \mathrm{C}$ for $14 \mathrm{~h}$ and then the number of bacterial colonies was counted to obtain the $\mathrm{CFU}$ reduction efficiency in broth solutions.

\section{Results and discussion}

\subsection{Characterization of materials}

In this study, $\mathrm{Fe}_{3} \mathrm{O}_{4}$ nanoparticles were incorporated into $\mathrm{CP}$ platform for synthesis of $\mathrm{CP} @ \mathrm{Fe}_{3} \mathrm{O}_{4}$ with an enhanced photocatalytic activity and easily separation and recyclability. Fig. 1 shows SEM, EDAX mapping images and EDX spectra of $\mathrm{CP} @ \mathrm{Fe}_{3} \mathrm{O}_{4}$ composite. According to Fig. 1a, SEM image reveals $\mathrm{Fe}_{3} \mathrm{O}_{4}$ nanoparticles incorporated. In addition, the agglomeration of $\mathrm{Fe}_{3} \mathrm{O}_{4}$ nanoparticles on the platform of $\mathrm{CP}$ is visible in EDAX mapping images. The EDX spectra of $\mathrm{Fe}_{3} \mathrm{O}_{4} @ \mathrm{CP}$ composite (Fig. 1g) confirms presence of $\mathrm{C}, \mathrm{N}, \mathrm{O}$ and Fe in its structure and confirms its successful synthesis.

XPS analysis of $\mathrm{CP}, \mathrm{Fe}_{3} \mathrm{O}_{4}$ and $\mathrm{CP} @ \mathrm{Fe}_{3} \mathrm{O}_{4}$ are shown in Fig. 2. The high-resolution $\mathrm{C} 1 \mathrm{~s}$ spectrum of bare $\mathrm{CP}$ shows three bands at 284.81, 286.52 and $288.42 \mathrm{eV}$ corresponding to $\mathrm{C}-\mathrm{C} / \mathrm{C}=\mathrm{C}, \mathrm{C}-\mathrm{C} / \mathrm{C}=\mathrm{C}-\mathrm{N} /$ $\mathrm{C}-\mathrm{O}$ and $\mathrm{C}-\mathrm{C}-\mathrm{N} / \mathrm{N}^{+}=\mathrm{C}-\mathrm{O}-$, respectively. $\mathrm{C} 1$ s spectrum of $\mathrm{CP} @ \mathrm{Fe}_{3} \mathrm{O}_{4}$ exhibits the same bands as $\mathrm{CP}$ spectrum. However, the observed band at $288.42 \mathrm{eV}$ was shifted to $287.31 \mathrm{eV}$ in $\mathrm{CP} @ \mathrm{Fe}_{3} \mathrm{O}_{4}$ along with an enlargement in the band, which could be due to the contribution of $\mathrm{C}-\mathrm{O}-\mathrm{Fe}$ bonding. The high-resolution $\mathrm{O} 1 \mathrm{~s}$ spectrum of bare $\mathrm{Fe}_{3} \mathrm{O}_{4}$ shows a single peak centered at $530.4 \mathrm{eV}$ that is associated to $\mathrm{Fe}-\mathrm{O}$. While, high-resolution $\mathrm{O} 1 \mathrm{~s}$ spectrum of $\mathrm{CP} @ \mathrm{Fe}_{3} \mathrm{O}_{4}$ shows a peak at $531.2 \mathrm{eV}$ resulting from the combination of $\mathrm{Fe}-\mathrm{O}$ and $\mathrm{Fe}-\mathrm{O}-\mathrm{C}$. The $\mathrm{Fe}-\mathrm{O}-\mathrm{C}$ bonds can be formed as a bridge between $\mathrm{CP}$ and $\mathrm{Fe}_{3} \mathrm{O}_{4}$ [27]. High-resolution N1s spectra of $\mathrm{CP}$ and $\mathrm{CP} @ \mathrm{Fe}_{3} \mathrm{O}_{4}$ show one peak at around $400 \mathrm{eV}$ due to $\mathrm{C}-\mathrm{N}$ in $\mathrm{CP}$ platform bonds $\mathrm{N}-\mathrm{C}=\mathrm{O}, \mathrm{N}-\mathrm{C}=\mathrm{N}$ and $\mathrm{N}-(\mathrm{C})_{3}$. High-resolution $\mathrm{Fe} 2 \mathrm{p}$ spectrum of $\mathrm{Fe}_{3} \mathrm{O}_{4}$ exhibits two distinct peaks for $\mathrm{Fe}_{2} \mathrm{p}_{3 / 2}$ and $\mathrm{Fe} 2 \mathrm{p}_{1 / 2}$ corresponded to $\mathrm{Fe}_{3} \mathrm{O}_{4}$ species. However, the incorporation of $\mathrm{Fe}_{3} \mathrm{O}_{4}$ nanoparticles into $\mathrm{FCP}$ was confirmed with EDAX mapping images, the intensities of Fe2p peaks were very weak in 

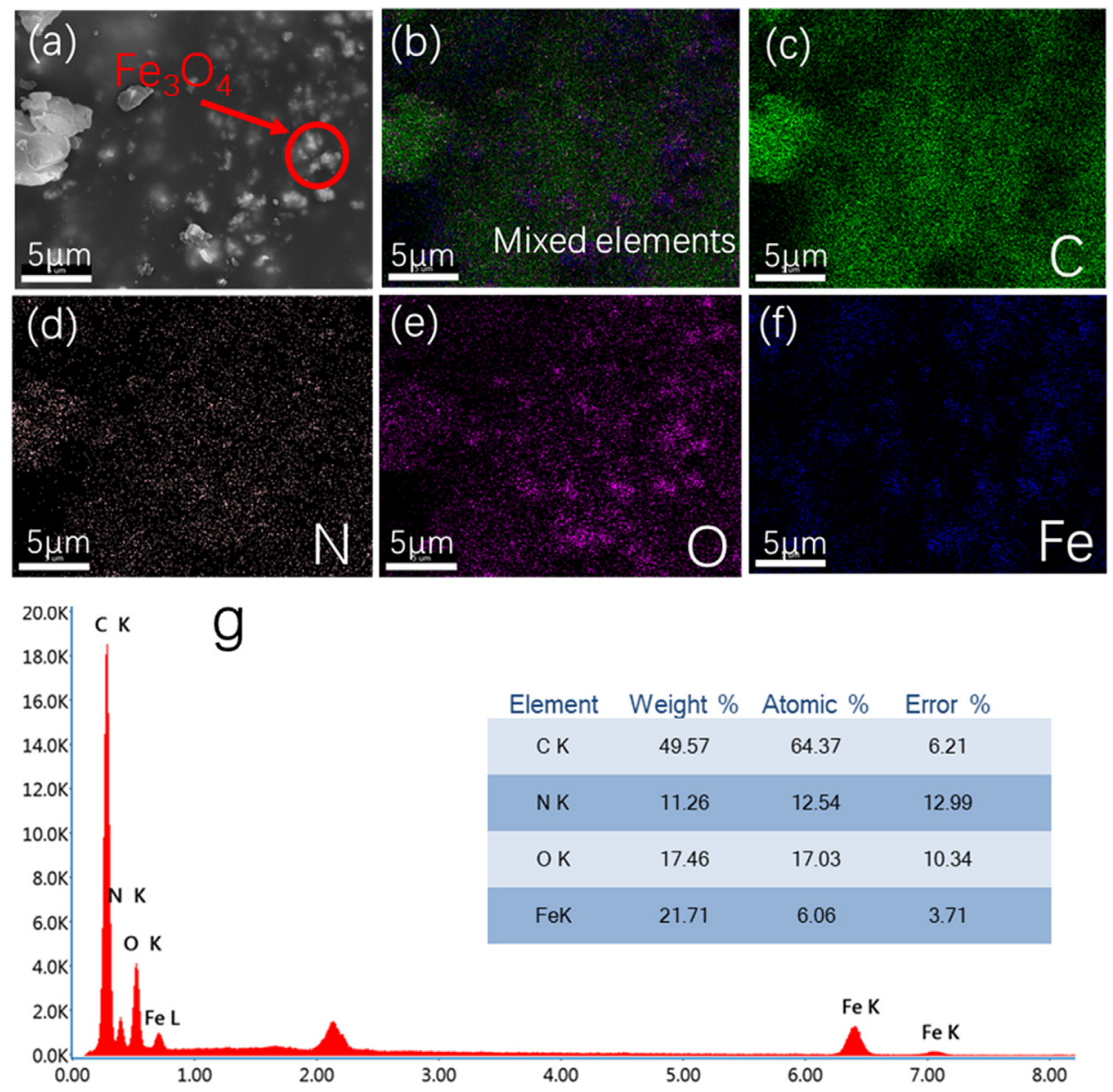

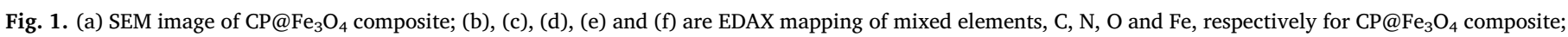
(g) EDAX spectrum of $\mathrm{CP} @ \mathrm{Fe}_{3} \mathrm{O}_{4}$ composite.

$\mathrm{CP} @ \mathrm{Fe}_{3} \mathrm{O}_{4}$ which is due to the coverage of most of $\mathrm{Fe}_{3} \mathrm{O}_{4}$ particles by $\mathrm{CP}$ layer.

The XRD patterns of $\mathrm{Fe}_{3} \mathrm{O}_{4}$ and $\mathrm{CP} @ \mathrm{Fe}_{3} \mathrm{O}_{4}$ (Fig. 3a) showcase diffraction peaks corresponded to pure magnetite $\mathrm{Fe}_{3} \mathrm{O}_{4}$. Thermogravimetry (TG) and Differential Scanning Calorimetry (DSC) spectra of $\mathrm{CP}$ and $\mathrm{CP} @ \mathrm{Fe}_{3} \mathrm{O}_{4}$ are shown in Fig. $3 \mathrm{~b}$ and c, respectively. TG and DSC analysis (heated from 30 to $600{ }^{\circ} \mathrm{C}$ ) were performed on non-calcined $\mathrm{CP}$ and $\mathrm{CP} @ \mathrm{Fe}_{3} \mathrm{O}_{4}$ samples to check the effect of calcination on the thermal stability of samples. TG curves show two main stages of mass loss. The first one between 80 and $200{ }^{\circ} \mathrm{C}$ is attributed to the removal of organic solvent and physically/chemically bounded $\mathrm{H}_{2} \mathrm{O}$ accompanied by a small mass loss of about $12 \%$ and $4 \%$ for $\mathrm{CP}$ and $\mathrm{CP} @ \mathrm{Fe}_{3} \mathrm{O}_{4}$, respectively. The second stage was occurred in the temperature range of 370 to $440{ }^{\circ} \mathrm{C}$ associated with a DSC endothermic peak at around $410{ }^{\circ} \mathrm{C}$ which is due to the decomposition of PVP, causing a total mass loss of 91.90 and $57.4 \%$ for $\mathrm{CP}$ and $\mathrm{CP} @ \mathrm{Fe}_{3} \mathrm{O}_{4}$, respectively.

Fig. 3d and e displays cyclic voltammetry (CV) and linear sweep voltammetry (LSV) of $\mathrm{CP}$ and $\mathrm{CP} @ \mathrm{Fe}_{3} \mathrm{O}_{4}$, respectively. It can be seen from the results of $\mathrm{CV}$ that the addition of $\mathrm{Fe}_{3} \mathrm{O}_{4}$ to $\mathrm{CP}$ platform has no effect on the onsets of oxidation and reduction potentials. However, LSV curve of $\mathrm{CP} @ \mathrm{Fe}_{3} \mathrm{O}_{4}$ shows two-step pathway which could be due to the enhanced electrocatalytic activity and better oxygen reduction reaction (ORR) [28]. UV-DRS spectra of photocatalyst samples are shown in Fig. 3f. Clearly, the introduction of $\mathrm{Fe}_{3} \mathrm{O}_{4}$ into $\mathrm{CP}$ platform results in better visible light response.

The photocatalytic ability of $\mathrm{CP} @ \mathrm{Fe}_{3} \mathrm{O}_{4}$ was tested for the reduction of $\mathrm{Cr}(\mathrm{VI})$, oxidation of $\mathrm{MB}$ and inactivation of $E$. coli and $P A$ in water. For comparison, the photocatalytic efficiency of bare $\mathrm{Fe}_{3} \mathrm{O}_{4}$ was evaluated for $\mathrm{Cr}(\mathrm{VI})$ reduction under UV-visible and visible light
(> $420 \mathrm{~nm}$ ) irradiations (Fig. 4a). The adsorption efficiency of bare $\mathrm{Fe}_{3} \mathrm{O}_{4}$ towards $\mathrm{Cr}(\mathrm{VI})$ solution was found as $8 \%$ within $60 \mathrm{~min}$. In terms of $\mathrm{Fe}_{3} \mathrm{O}_{4} / \mathrm{UV}$-visible and $\mathrm{Fe}_{3} \mathrm{O}_{4}$ /visible systems, the reduction efficiency towards $\mathrm{Cr}(\mathrm{VI})$ solution with initial concentration of $20 \mathrm{mgL}^{-1}$ and $\mathrm{pH}=4$ was observed as $21 \%$ and $12 \%$, respectively. However, the addition of tartaric acid as ROSs and hole scavenger to these two latter systems enhanced the photocatalytic reduction of $\mathrm{Cr}(\mathrm{VI})$ species to $80 \%$ and $37 \%$, respectively. The results suggest that the $\mathrm{Fe}_{3} \mathrm{O}_{4}$ nanoparticles can be photoexcited and produce $\mathrm{e}^{-}$and $\mathrm{h}^{+}$. The reduction potential of the conduction band of $\mathrm{Fe}_{3} \mathrm{O}_{4}$ is not able to reduce $\mathrm{O}_{2}$ to $\mathrm{O}_{2}{ }^{\cdot-}$ species, hence two-step reduction occurs for reduction of $\mathrm{O}_{2}$ to $\mathrm{H}_{2} \mathrm{O}_{2}$ followed by formation of ${ }^{\circ} \mathrm{OH}$ on the conduction band [29]. Direct reduction of $\mathrm{Cr}(\mathrm{VI})$ species can happen by photogenerated electrons on the conduction band, meanwhile, the presence of tartaric acid as a scavenger for positive hole and reactive oxygen species (ROSs) results in better electrons generation with longer life. Fig. $4 \mathrm{~b}$ shows the photocatalytic reduction of $\mathrm{Cr}(\mathrm{VI})$ by $\mathrm{CP} @ \mathrm{Fe}_{3} \mathrm{O}_{4}$. According to the results inserted in Fig. 4b, the reduction efficiency of $\mathrm{CP} @ \mathrm{Fe}_{3} \mathrm{O}_{4}$ is much higher than bare $\mathrm{Fe}_{3} \mathrm{O}_{4}$ under UV- visible and visible lights which is attributed to the high photoactivity of $\mathrm{CP} @ \mathrm{Fe}_{3} \mathrm{O}_{4}$. Under UV-visible light, $52 \%$ of $\mathrm{Cr}(\mathrm{VI})$ solution was reduced using $\mathrm{CP} @ \mathrm{Fe}_{3} \mathrm{O}_{4}$ within $60 \mathrm{~min}$, while a total reduction was found at $30 \mathrm{~min}$ using $\mathrm{CP} @ \mathrm{Fe}_{3} \mathrm{O}_{4} / \mathrm{TA}$. Under visible light, $30 \%$ and $65 \%$ of $\mathrm{Cr}(\mathrm{VI})$ solution within $60 \mathrm{~min}$ were reduced by $\mathrm{CP} @ \mathrm{Fe}_{3} \mathrm{O}_{4}$ and $\mathrm{CP} @ \mathrm{Fe}_{3} \mathrm{O}_{4} / \mathrm{TA}$ systems, respectively.

These reduction reactions are carrying out with the following proposed mechanism. CP can absorb visible light and produces both electrons and ROSs. Unlike $\mathrm{Fe}_{3} \mathrm{O}_{4}$, most of ROS $\left(\mathrm{O}_{2}{ }^{-}{ }^{-}, \mathrm{H}_{2} \mathrm{O}_{2}\right.$ and $\left.{ }^{\circ} \mathrm{OH}\right)$, which affect the reduction of $\mathrm{Cr}(\mathrm{VI})$, can be obtained via single or multi-step reduction of dissolved $\mathrm{O}_{2}$. Furthermore, $\mathrm{O}_{2}$ can compete with 
(a)

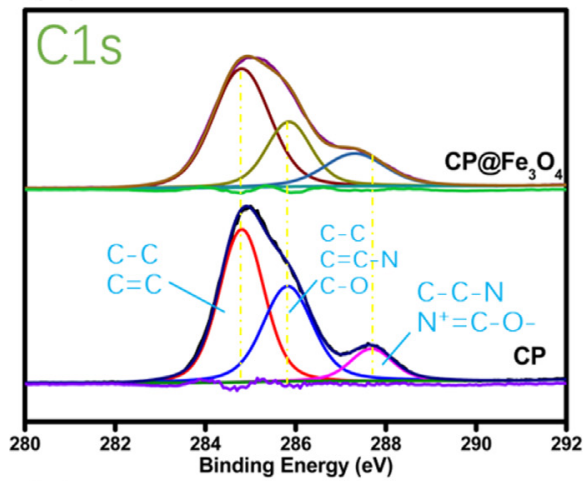

(c)

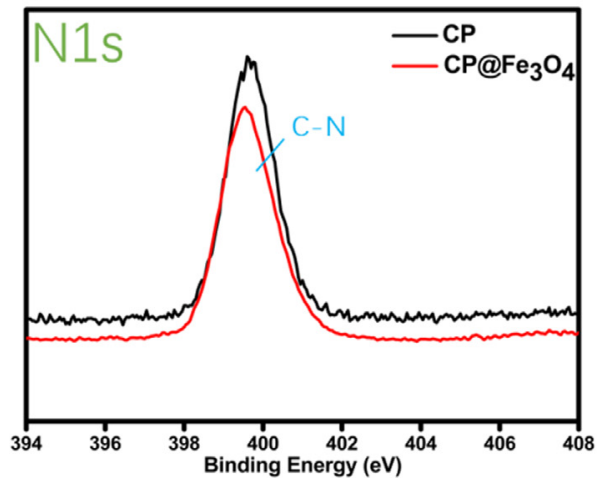

(b)

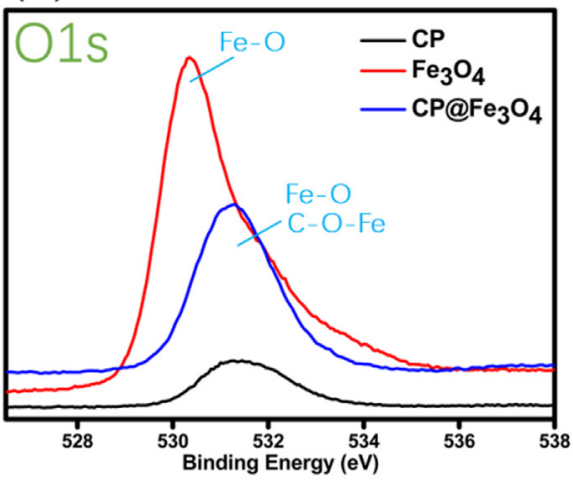

(d)

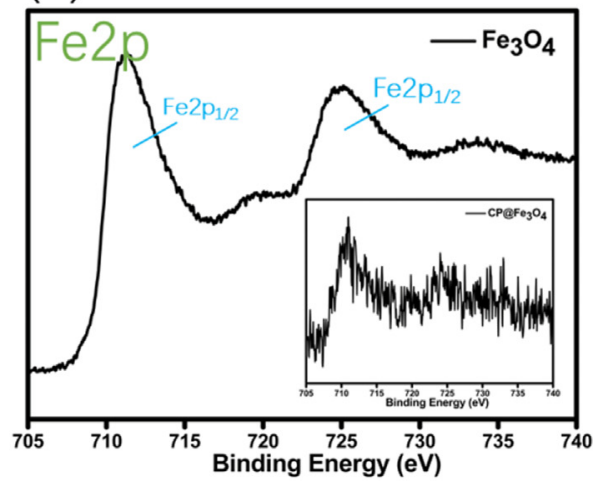

Fig. 2. High-resolution C1s, O1s, N1s and Fe2p spectra of materials.

$\mathrm{Cr}(\mathrm{VI})$ species to consume photogenerated electrons on the conduction band of CP.

To investigate this point, an experiment was carried out for reduction of $\mathrm{Cr}(\mathrm{VI})$ solution under visible light using $\mathrm{CP} @ \mathrm{Fe}_{3} \mathrm{O}_{4}$ in saturated $\mathrm{N}_{2}$ atmosphere without tartaric acid. As showed in Fig. 4b, a total reduction of $\mathrm{Cr}(\mathrm{VI})$ was found within $60 \mathrm{~min}$. This suggests the participation of $\mathrm{O}_{2}$ to consume photogenerated electrons and produce ROSs which inhibit the reduction of $\mathrm{Cr}(\mathrm{VI})$. Additionally, $\mathrm{OH}$ can be produced also from $\mathrm{h}^{+}$of $\mathrm{Fe}_{3} \mathrm{O}_{4}$ particles in $\mathrm{CP} @ \mathrm{Fe}_{3} \mathrm{O}_{4}$ composite. The Charges transfer between $\mathrm{CP}$ and $\mathrm{Fe}_{3} \mathrm{O}_{4}$ is likely to happen, wherein, the transfer of photogenerated electrons from the conduction band of CP platform, which contains electron-rich TCTA with high reduction potential (LUMO level of TCTA is $2.48 \mathrm{~V}$ at pH 7), to the conduction band of $\mathrm{Fe}_{3} \mathrm{O}_{4}$ is possible, likewise the positive holes can be transferred (a)

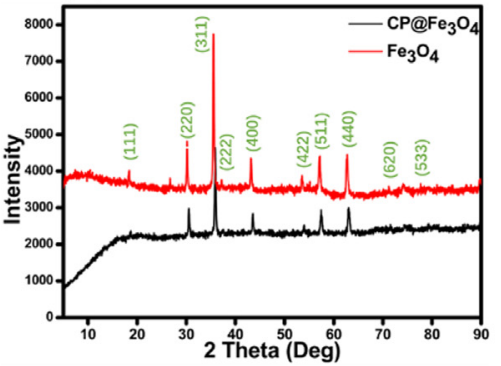

(d)

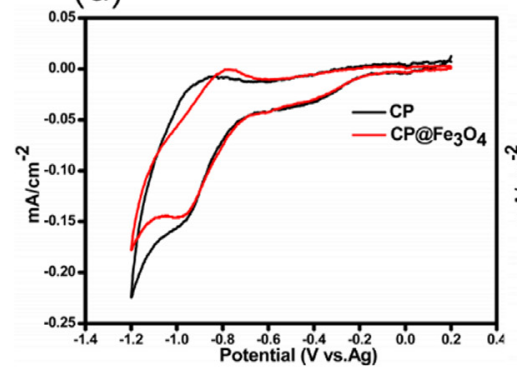

(b)

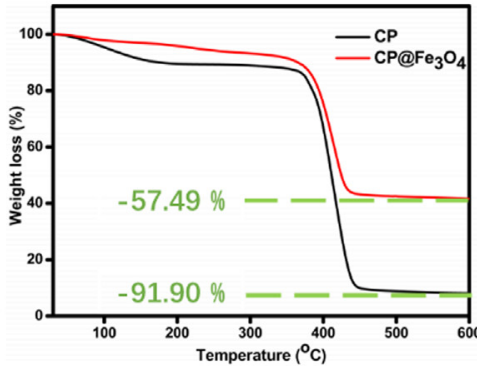

(e)

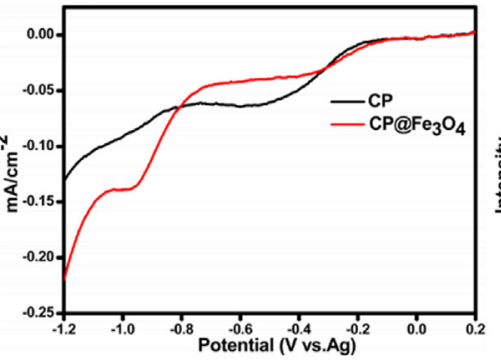

(c)

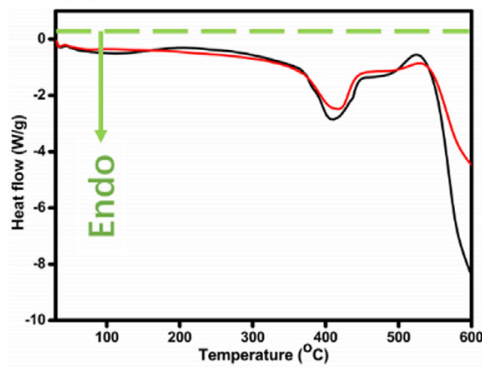

$(f)$

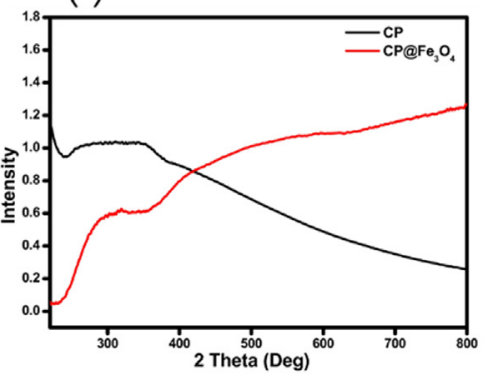

Fig. 3. (a) XRD patterns for $\mathrm{Fe}_{3} \mathrm{O}_{4}$ and $\mathrm{CP} @ \mathrm{Fe}_{3} \mathrm{O}_{4}$, (b) TG spectra for $\mathrm{CP}$ and $\mathrm{CP}_{\mathrm{F}} \mathrm{Fe}_{3} \mathrm{O}_{4}$, (c) $\mathrm{DSC}$ for $\mathrm{CP}$ and $\mathrm{CP} @ \mathrm{Fe}_{3} \mathrm{O}_{4}$, (d) $\mathrm{CV}$ analysis for $\mathrm{CP}$ and $\mathrm{CP} @ \mathrm{Fe} \mathrm{O}_{4}$, (e) $\mathrm{LSV}$ analysis for CP and CP@ $\mathrm{Fe}_{3} \mathrm{O}_{4}$, and (f) UV-DRS spectra for CP and $\mathrm{CP} @ \mathrm{Fe}_{3} \mathrm{O}_{4}$. 
(a)

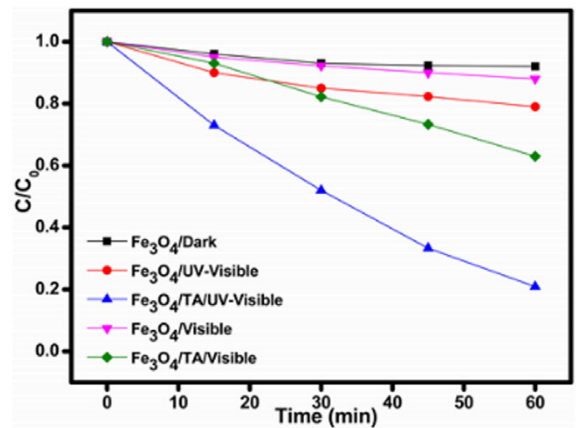

(c)

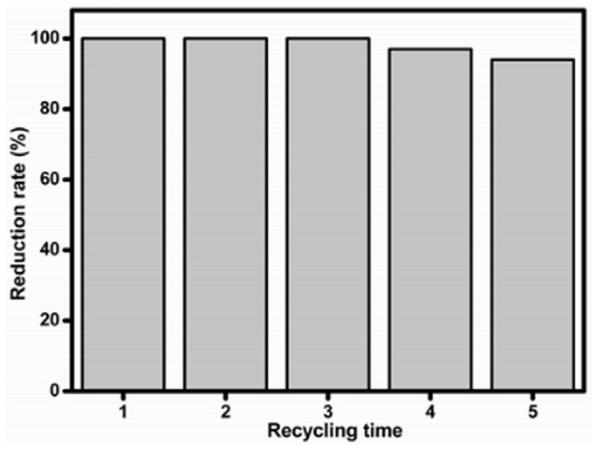

(b)

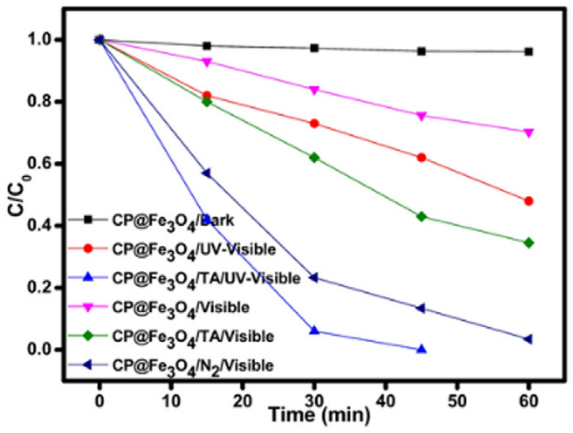

(d)

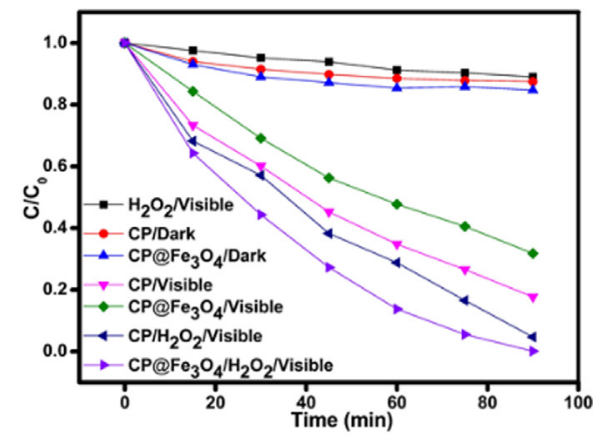

Fig. 4. (a) and (b) Photocatalytic reduction of $\mathrm{Cr}(\mathrm{VI})$ with initial concentration of $20 \mathrm{mgL}^{-1}$ using $\mathrm{Fe}_{3} \mathrm{O}_{4}$ and $\mathrm{CP} @ \mathrm{Fe}_{3} \mathrm{O}_{4}$ under visible light, respectively, (c) recycling tests of $\mathrm{CP} @ \mathrm{Fe}_{3} \mathrm{O}_{4}$ for $\mathrm{Cr}(\mathrm{VI})$ reduction, (d) Photocatalytic oxidation of $\mathrm{MB}$ solution with initial concentration of $10 \mathrm{mgL}^{-1}$ using CP and CP@ $\mathrm{Fe}_{3} \mathrm{O}_{4}$ under visible light irradiation.

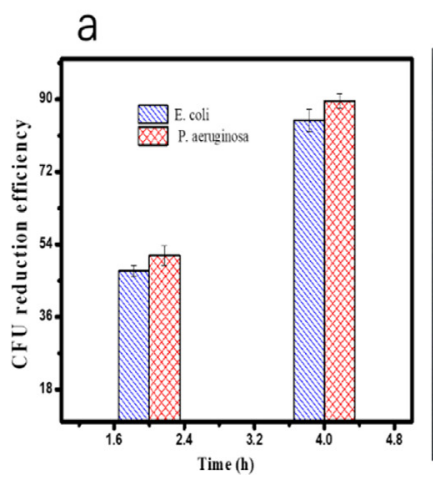

b

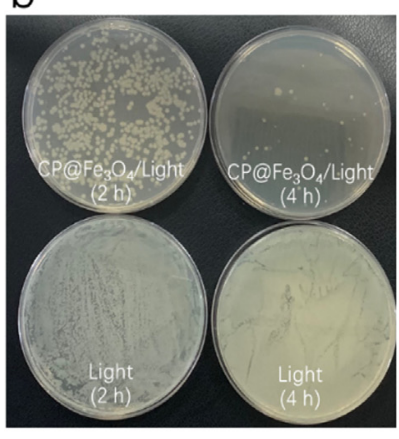

C

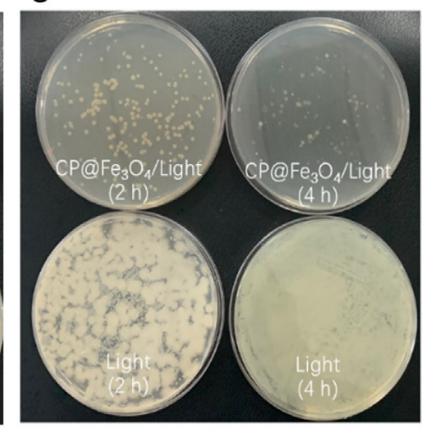

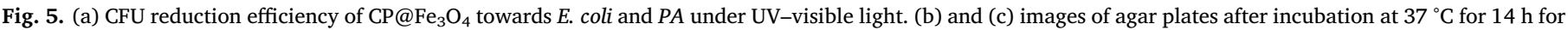
E. coli and $P A$, respectively.

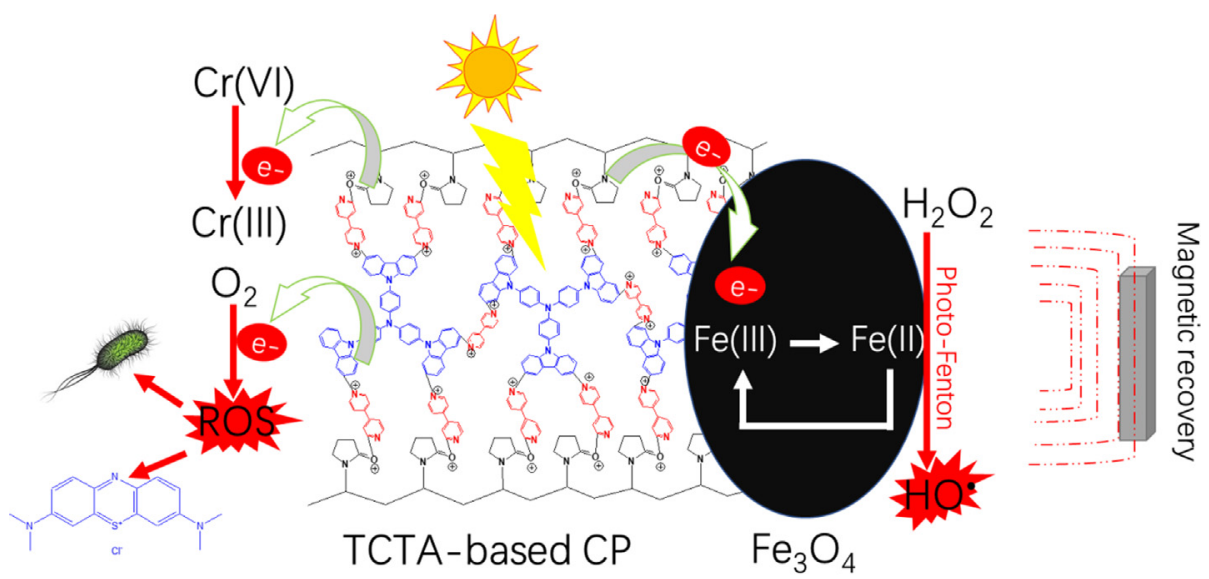

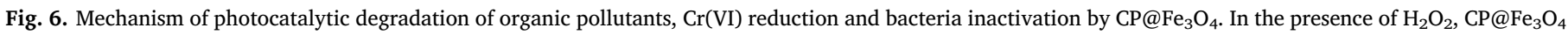
can catalyze Fenton reaction. 
from the valence band of $\mathrm{Fe}_{3} \mathrm{O}_{4}$ to $\mathrm{CP}$ platform. The electrons of $\mathrm{CP}$ transfer to $\mathrm{Fe}_{3} \mathrm{O}_{4}$ and reduce $\mathrm{Fe}(\mathrm{III})$ to $\mathrm{Fe}(\mathrm{II})$ species, as a result, the $\mathrm{Fe}$ (II) can reduce $\mathrm{Cr}(\mathrm{VI})$ directly.

Recycling tests for photocatalytic reduction of $\mathrm{Cr}(\mathrm{VI})$ with $\mathrm{CP} @$ $\mathrm{Fe}_{3} \mathrm{O}_{4}$ were performed to check the stability of composite material (Fig. 4c). To avoid the loss of photocatalyst mass during multi-sampling, the concentration of $\mathrm{Cr}(\mathrm{VI})$ solution was measured only once after $60 \mathrm{~min}$. The results revealed that after five cycles of reduction process, the reduction efficiency of $\mathrm{CP} @ \mathrm{Fe}_{3} \mathrm{O}_{4}$ composite decreases partially.

The photocatalytic oxidation of MB solution under visible light by pure $\mathrm{CP}$ and $\mathrm{CP} @ \mathrm{Fe}_{3} \mathrm{O}_{4}$ was carried out and the results are showed in Fig. 4d. Obviously, pure $\mathrm{CP}$ showed better degradation of MB compared to $\mathrm{CP} @ \mathrm{Fe}_{3} \mathrm{O}_{4}$ composite. It seems that pure $\mathrm{CP}$ is more active under visible light than $\mathrm{CP} @ \mathrm{Fe}_{3} \mathrm{O}_{4}$ to produce ROSs under these conditions. Even with such slight decrease in the efficiency of $\mathrm{MB}$ degradation, $\mathrm{CP} @ \mathrm{Fe}_{3} \mathrm{O}_{4}$ is more recommended for real-world wastewater remediation because of the easy recovery and recycling. On the contrary, in the presence of $10^{-5} \mathrm{M}$ of $\mathrm{H}_{2} \mathrm{O}_{2}, \mathrm{CP} @ \mathrm{Fe}_{3} \mathrm{O}_{4}$ showed better MB oxidation than pure $\mathrm{CP}$. Herein, photo-Fenton reaction catalyzed by $\mathrm{Fe}_{3} \mathrm{O}_{4}$ may take place for producing more ROSs as shown in Fig. 6. As abovementioned, the transferred electrons from photoexcited CP to $\mathrm{Fe}_{3} \mathrm{O}_{4}$ resulted in the reduction of $\mathrm{Fe}(\mathrm{III})$ to $\mathrm{Fe}(\mathrm{II})$ species, which in turn $\mathrm{Fe}(\mathrm{II})$ reacts with the added $\mathrm{H}_{2} \mathrm{O}_{2}$ to generate ${ }^{\circ} \mathrm{OH}$ radicals. It is important to point out that $\mathrm{Fe}_{3} \mathrm{O}_{4}$ itself could contain a little amount of $\mathrm{Fe}(\mathrm{II})$ ions on its surface, which can react directly with $\mathrm{H}_{2} \mathrm{O}_{2}$.

The photocatalytic antibacterial activity of $\mathrm{CP} @ \mathrm{Fe}_{3} \mathrm{O}_{4}$ was checked for the inactivation of two types of bacteria i.e., E. coli and Pseudomonas Aeruginosa $(P A)$. Liquid solutions containing E. coli or $P A$ were subjected to photocatalytic treatment under UV-visible light. Control experiments under UV-visible light without photocatalyst were carried out as well. Afterward, samples after 2 and $4 \mathrm{~h}$ were collected and spread on agar plates, and then these agar plates were incubated at $37{ }^{\circ} \mathrm{C}$ for $14 \mathrm{~h}$. The results of CFU reduction efficiency are shown in Fig. 5a. CFU reduction efficiency using $\mathrm{CP} @ \mathrm{Fe}_{3} \mathrm{O}_{4}$ under UV-visible light was around $85 \%$ and $90 \%$ for $E$. coli and $P A$, respectively. The results of plate test (Fig. 5b, c) showed a significant inhibition of bacteria in broth solution using $\mathrm{CP} @ \mathrm{Fe}_{3} \mathrm{O}_{4}$ under UV-visible, while, intense growth in control plates (without photocatalyst) which further evidences the inhibition of growth was due to generated of ROSs species by $\mathrm{CP} @ \mathrm{Fe}_{3} \mathrm{O}_{4}$ under light.

The inactivation of bacteria is occurred by photogenerated ROSs such as $\mathrm{O}_{2}{ }^{\cdot-}, \mathrm{h}^{+}, \cdot \mathrm{OH}$ and $\mathrm{H}_{2} \mathrm{O}_{2}$. It was reported that ROSs with longer lifetime are more efficient for the inactivation of bacteria, unlike the oxidation of organics [30]. ROSs with longer lifetime are able to damage the bacteria by bursting and collapsing of bacterial membrane and cells. Therefore, $\mathrm{H}_{2} \mathrm{O}_{2}$ and $\mathrm{O}_{2}{ }^{\cdot-}$, might be more efficient than ${ }^{\circ} \mathrm{OH}$. $\mathrm{H}_{2} \mathrm{O}_{2}$ can be produced via the reduction of $\mathrm{O}_{2}{ }^{-}$by photogenerated electrons in $\mathrm{CP} @ \mathrm{Fe}_{3} \mathrm{O}_{4}$ system. Besides the toxic effect of $E$. Coli or $P A$, these species are considered as major faecal contaminants in water purification stations and main contributor for biofouling in membrane systems $[26,31]$.

\section{Conclusions}

Soft-magnetically recoverable photoactive $\mathrm{CP} @ \mathrm{Fe}_{3} \mathrm{O}_{4}$ showed excellent photocatalytic activity for $\mathrm{Cr}(\mathrm{VI})$ reduction, $\mathrm{MB}$ oxidation and bacteria inactivation. Also, the incorporation of $\mathrm{Fe}_{3} \mathrm{O}_{4}$ in $\mathrm{CP}$ platform facilitates the recovery of the photocatalyst after the water treatment via the application of an external magnetic field. In terms of photoactivity, $\mathrm{CP} @ \mathrm{Fe}_{3} \mathrm{O}_{4}$ showed an excellent photocatalytic reduction of $\mathrm{Cr}$ (VI) compare to bare $\mathrm{CP}$ and $\mathrm{Fe}_{3} \mathrm{O}_{4}$ under UV-visible and visible light. The incorporation of $\mathrm{Fe}_{3} \mathrm{O}_{4}$ into $\mathrm{CP}$ resulted in lower oxidation of $\mathrm{MB}$ compared to bare CP. However the $\mathrm{CP} @ \mathrm{Fe}_{3} \mathrm{O}_{4}$ was more efficient in presence of $\mathrm{H}_{2} \mathrm{O}_{2}$ than bare $\mathrm{CP}$, due to the Fenton reaction achieved by the $\mathrm{Fe}(\mathrm{II})$ produced via the reduction of $\mathrm{Fe}(\mathrm{III})$ of $\mathrm{Fe}_{3} \mathrm{O}_{4}$ by photogenerated electrons coming from $\mathrm{CP}$ platform. Interestingly the $\mathrm{CP} @ \mathrm{Fe}_{3} \mathrm{O}_{4}$ composite showed very good photocatalytic antibacterial activity against $E$. coli and Pseudomonas Aeruginosa in water. Based on the obtained results, $\mathrm{CP} @ \mathrm{Fe}_{3} \mathrm{O}_{4}$ composite, can be used as an efficient photocatalyst for water remediation and disinfection in wastewater treatment.

\section{Declaration of Competing Interest}

The authors declare that they have no known competing financial interests or personal relationships that could have appeared to influence the work reported in this paper.

\section{Acknowledgements}

This work was supported by the National Natural Science Foundation of China $(21777106,21777176)$, the National Major Science \& Technology Program for Water Pollution Control \& Treatment (2017ZX07202).

\section{Appendix A. Supplementary material}

Supplementary data to this article can be found online at https:// doi.org/10.1016/j.seppur.2020.116954.

\section{References}

[1] G. Crini, E. Lichtfouse, Advantages and disadvantages of techniques used for wastewater treatment, Environ. Chem. Lett. 17 (2019) 145-155.

[2] S. Dong, J. Feng, M. Fan, Y. Pi, L. Hu, X. Han, M. Liu, J. Sun, J. Sun, Recent developments in heterogeneous photocatalytic water treatment using visible lightresponsive photocatalysts: a review, RSC Adv. 5 (2015) 14610-14630.

[3] M.N. Chong, B. Jin, C.W. Chow, C. Saint, Recent developments in photocatalytic water treatment technology: a review, Water Res. 44 (2010) 2997-3027.

[4] S. Sun, X. Yu, Q. Yang, Z. Yang, S. Liang, Mesocrystals for photocatalysis: a comprehensive review on synthesis engineering and functional modifications, Nanoscale Adv. 1 (2019) 34-63.

[5] Fen Zhang, Yongcai Zhang, Geshan Zhang, Zhanjun Yang, Dionysios D. Dionysiou, Aiping Zhu, Exceptional synergistic enhancement of the photocatalytic activity of $\mathrm{SnS}_{2}$ by coupling with polyaniline and $\mathrm{N}$-doped reduced graphene oxide, Appl. Catal. B. 236 (2018) 53-63.

[6] L.G. Devi, R. Kavitha, A review on non metal ion doped titania for the photocatalytic degradation of organic pollutants under UV/solar light: role of photogenerated charge carrier dynamics in enhancing the activity, Appl. Catal. B Environ. 140 (2013) 559-587.

[7] M. Nolan, Surface modification of $\mathrm{TiO}_{2}$ with metal oxide nanoclusters: a route to composite photocatalytic materials, Chem. Commun. 47 (2011) 8617-8619.

[8] J.H. Shah, M. Fiaz, M. Athar, J. Ali, M. Rubab, R. Mehmood, S.U.U. Jamil, R. Djellabi, Facile synthesis of N/B-double-doped $\mathrm{Mn}_{2} \mathrm{O}_{3}$ and $\mathrm{WO}_{3}$ nanoparticles for dye degradation under visible light, Environ. Technol. 1-10 (2019).

[9] X. Zhang, T. Peng, S. Song, Recent advances in dye-sensitized semiconductor systems for photocatalytic hydrogen production, J. Mater. Chem. A 4 (2016) 2365-2402.

[10] Z. Youssef, P. Arnoux, L. Colombeau, J. Toufaily, T. Hamieh, C. Frochot, T. RoquesCarmes, Comparison of two procedures for the design of dye-sensitized nanoparticles targeting photocatalytic water purification under solar and visible light, J. Photochem. Photobiol., A. 356 (2018) 177-192.

[11] Z. Zhang, W. Wang, L. Wang, S. Sun, Enhancement of visible-light photocatalysis by coupling with narrow-band-gap semiconductor: a case study on $\mathrm{Bi}_{2} \mathrm{~S}_{3} / \mathrm{Bi}_{2} \mathrm{WO}_{6}$, ACS Appl. Mater. Interfaces 4 (2012) 593-597.

[12] H. Wang, L. Zhang, Z. Chen, J. Hu, S. Li, Z. Wang, J. Liu, X. Wang, Semiconductor heterojunction photocatalysts: design, construction, and photocatalytic performances, Chem. Soc. Rev. 43 (2014) 5234-5244.

[13] R. Djellabi, B. Yang, K. Xiao, Y. Gong, D. Cao, H.M.A. Sharif, X. Zhao, C. Zhu, J. Zhang, Unravelling the mechanistic role of Ti-OC bonding bridge at titania/lignocellulosic biomass interface for Cr (VI) photoreduction under visible light, J. Colloid Interface Sci. 553 (2019) 409-417.

[14] J. Ge, Y. Zhang, S.-J. Park, Recent advances in carbonaceous photocatalysts with enhanced photocatalytic performances: a mini review, Materials 12 (2019) 1916.

[15] A.Y. Shan, T.I.M. Ghazi, S.A. Rashid, Immobilisation of titanium dioxide onto supporting materials in heterogeneous photocatalysis: a review, Appl. Catal., A. 389 (2010) 1-8.

[16] R. Du, Q. Zhao, Z. Zheng, W. Hu, J. Zhang, 3D self-supporting porous magnetic assemblies for water remediation and beyond, Adv. Energy Mater. 6 (2016) 1600473.

[17] R. Djellabi, B. Yang, H.M.A. Sharif, J. Zhang, J. Ali, X. Zhao, Sustainable and easy recoverable magnetic $\mathrm{TiO}_{2}$-lignocellulosic biomass@ $\mathrm{Fe}_{3} \mathrm{O}_{4}$ for solar photocatalytic 
water remediation, J. Clean. Prod. 233 (2019) 841-847.

[18] H.M.A. Sharif, A. Mahmood, H.-Y. Cheng, R. Djellabi, J. Ali, W.-L. Jiang, S. S. Wang, M.R. Haider, N. Mahmood, A.-J. Wang, $\mathrm{Fe}_{3} \mathrm{O}_{4}$ nanoparticles coated with EDTA and Ag nanoparticles for the catalytic reduction of organic dyes from wastewater, ACS Appl Nano Mater. 2 (2019) 5310-5319.

[19] R.D. Ambashta, M. Sillanpää, Water purification using magnetic assistance: a review, J. Hazard. Mater. 180 (2010) 38-49.

[20] P. Mishra, S. Patnaik, K. Parida, An overview of recent progress on noble metal modified magnetic $\mathrm{Fe}_{3} \mathrm{O}_{4}$ for photocatalytic pollutant degradation and $\mathrm{H}_{2}$ evolution, Catal. Sci 9 (2019) 916-941.

[21] W. Wang, Q. Mao, H. He, M. Zhou, $\mathrm{Fe}_{3} \mathrm{O}_{4}$ nanoparticles as an efficient heterogeneous Fenton catalyst for phenol removal at relatively wide $\mathrm{pH}$ values, Water Sci. Technol. 68 (2013) 2367-2373.

[22] Z. He, C. Gao, M. Qian, Y. Shi, J. Chen, S. Song, Electro-Fenton process catalyzed by $\mathrm{Fe}_{3} \mathrm{O}_{4}$ magnetic nanoparticles for degradation of CI Reactive Blue 19 in aqueous solution: operating conditions, influence, and mechanism, Ind. Eng. Chem. Res. 53 (2014) 3435-3447.

[23] S.-T. Yang, W. Zhang, J. Xie, R. Liao, X. Zhang, B. Yu, R. Wu, X. Liu, H. Li, Z. Guo, $\mathrm{Fe}_{3} \mathrm{O}_{4} @ \mathrm{SiO}_{2}$ nanoparticles as a high-performance Fenton-like catalyst in a neutral environment, RSC Adv. 5 (2015) 5458-5463.

[24] B. Mercyrani, R. Hernandez-Maya, M. Solís-López, C. Th-Th, S. Velumani, Photocatalytic degradation of Orange $\mathrm{G}$ using $\mathrm{TiO}_{2} / \mathrm{Fe}_{3} \mathrm{O}_{4}$ nanocomposites, J. Mater. Sci-Mater. El. 29 (2018) 15436-15444.

[25] J. Ali, L. Wang, H. Waseem, H.M.A. Sharif, R. Djellabi, C. Zhang, G. Pan,
Bioelectrochemical recovery of silver from wastewater with sustainable power generation and its reuse for biofouling mitigation, J. Clean. Prod. 235 (2019) 1425-1437.

[26] S. Rana, U. Nazar, J. Ali, Q.U.A. Ali, N.M. Ahmad, F. Sarwar, H. Waseem, S.U.U. Jamil, Improved antifouling potential of polyether sulfone polymeric membrane containing silver nanoparticles: self-cleaning membranes, Environ. Technol. 39 (2018) 1413-1421.

[27] J. Lin, H. Liang, H. Jia, S. Chen, J. Guo, J. Qi, C. Qu, J. Cao, W. Fei, J. Feng, In situ encapsulated $\mathrm{Fe}_{3} \mathrm{O}_{4}$ nanosheet arrays with graphene layers as an anode for highperformance asymmetric supercapacitors, J. Mater. Chem. A 5 (2017) 24594-24601.

[28] S. Wang, D. Yu, L. Dai, Polyelectrolyte functionalized carbon nanotubes as efficient metal-free electrocatalysts for oxygen reduction, J. Am. Chem. Soc. 133 (2011) 5182-5185.

[29] U. Kurien, Z. Hu, H. Lee, A.P. Dastoor, P.A. Ariya, Radiation enhanced uptake of Hg 0 (g) on iron (oxyhydr) oxide nanoparticles, RSC Adv. 7 (2017) 45010-45021.

[30] W. Wang, L. Zhang, T. An, G. Li, H.-Y. Yip, P.-K. Wong, Comparative study of visible-light-driven photocatalytic mechanisms of dye decolorization and bacterial disinfection by B-Ni-codoped $\mathrm{TiO}_{2}$ microspheres: The role of different reactive species, Appl. Catal. B Environ. 108 (2011) 108-116.

[31] K. Khan, Y. Lu, M.A. Saeed, H. Bilal, H. Sher, H. Khan, J. Ali, P. Wang, H. Uwizeyimana, Y. Baninla, Prevalent fecal contamination in drinking water resources and potential health risks in Swat, Pakistan, J. Environ. Sci. 72 (2018) 1-12. 